\title{
KAJIAN PEMANFAATAN KADASTER LAUT DAN VISUALISASI 3 DIMENSI (Studi Kasus : Pulau Maratua, Berau, Kalimantan Timur)
}

\author{
Resti Yully Astuti ${ }^{1}$, Yanto Budisusanto ${ }^{2}$, Danar Guruh Pratomo ${ }^{3}$, Muhandis Sidqi ${ }^{4}$ \\ 1,2,3 Jurusan Teknik Geomatika, Fakultas Teknik Sipil Lingkungan dan Kebumian, \\ Institut Teknologi Sepuluh Nopember (ITS) \\ ${ }^{4}$ Direktorat Pengelolaan Ruang Laut. Kementerian kelautan dan perikanan RI \\ Restiyully18@gmail.com, yanto_b@geodesi.its.ac.id
}

\begin{abstract}
Abstrak
Sebagai salah satu negara kepulauan terbesar di dunia yang memiliki lebih dari 17.000 pulau dengan lautan seluas 2,9 juta $\mathrm{km}^{2}$. Indonesia memiliki wewenang mengelola ruang lautnya. Namun, kerangka kebijakan dan kelembagaan yang mengatur pemanfaatan ruang laut tersebut masih rumit. Sehingga perlu adanya pertimbangan dari aspek legal maupun teknis dalam penerapannya. Rencana Zonasi adalah rencana yang menentukan arah penggunaan sumber daya tiap-tiap satuan perencanaan disertai dengan penetapan struktur dan pola ruang pada kawasan perencanaan yang memuat kegiatan yang boleh dilakukan dan tidak boleh dilakukan serta kegiatan yang hanya dapat dilakukan setelah memperoleh izin. penelitian ini membuat peta dasar implementasi kadaster laut dan visualisasi 3 dimensi ruang laut berdasarkan kedalaman pada zona perikanan budidaya di Pulau Maratua sebagai salah satu dari 111 pulau kecil terluar. Metode yang digunakan dalam penelitian ini yaitu melakukan overlay pada data RZWP-3-K dan data eksisting pemanfaatan ruang laut untuk memperolah informasi wilayah KJA yang tidak sesuai dengan rencana zonasinya. Selanjutnya hasil overlay tersebut digabungkan dengan data kontur laut untuk memperoleh informasi kedalaman di wilayah yang tumpang tindih dan divisualisasikan menjadi model 3 dimensi. Dari hasil analisis peta dasar kadaster laut diketahui bahwa di Pulau Maratua saat ini terdapat 6 keramba jaring apung (KJA). Namun terdapat 3 KJA yang lokasinya tidak sesuai dengan rencana zonasi Pulau Maratua, sehingga terjadi tumpang tindih pemanfaatan ruang laut. Salah satu KJA yang tidak sesuai adalah KJA5, yang tumpang tindih dengan subzona perlindungan ekosistem. Pada KJA5 ini dibuat model 3 dimensi untuk menunjukkan pembagian pemanfaatan ruang laut berdasarkan pada kedalaman
\end{abstract}

Kata Kunci - Kadaster Laut, Keramba Jaring Apung (KJA), Visualisasi 3D.

\begin{abstract}
Indonesia is one of the largest archipelagic countries in the world which has more than 17,000 islands, surrounded by 2.9 million $\mathrm{km} 2$ of waters. The country has an authority to organize and manage the marine territory for the national development. However the policy and the institutional framework to govern the utilization of the marine space are still complicated. Thus the implementation of marine cadastre is needed. The implementation requires a study of both legal and technical aspects. The goverment already has the Coastal Area and Small Islands Zoning Plans (RZWP-3-K) which lis used to determine the direction of utilization of marine resource and as a reference for the issuance of the location permit in marine space management. This research aimed is to develope the base map of marine cadastreand $3 D$ visualization marine area based on the deep. This research studied the RZWP-3-K implementation in Maratua Island. This island is one of the 111 outermost small islands which already has marine management plan. The method used in this research is overlaying RZWP-3-K with exsisting data to get information about the floating net cages (KJA) which is not suited.Then, the result is compared with contour to build the 3D visualization. Based on the research, There are 6 floating net cages (KJA) in this area. But in Maratua Island's waters consist of 3 KJA that are not appropriate with the plan, one of them is KJA 5 that located in ecosystem protected subzone. Thus, this research developed $3 D$ visualization based on the deep of KJA 5.
\end{abstract}

Keywords - marine cadastre, Floating Net Cages (KJA), 3D Visualization 


\section{PENDAHULUAN}

Indonesia adalah negara kepulauan terbesar dunia yang memiliki 17.504 pulau dengan luas daratan NKRI sebesar 1.910.931,32 km2 (BPS-RI, 2015). Sedangkan untuk wilayah laut Indonesia dalam buku statistik Kementrian Kelautan dan Perikanan (KKP) tahun 2011 menyatakan bahwa laut Indonesia memiliki luas laut territorial yang berjarak 12 mil laut dari garis pangkal kepulauan adalah sebesar 284.210,900 km2 dan luas Zona Ekonomi Eksklusif (ZEE) yang berjarak 200 mil laut dari garis pangkal adalah sebesar 2.981.211,000 $\mathrm{km} 2$. Dengan wilayah laut yang luas tersebut, kebutuhan ekonomi, sosial, dan lingkungan perlu diatur dengan efektif. Negara memiliki wewenang untuk mengelola ruang lautnya, namun kerangka kebijakan dan kelembagaan yang mengatur pemanfaatan ruang laut tersebut masih rumit. Sesuai ketentuan Pasal 33 ayat (3) UUD 1945 juncto UUPA, UNCLOS juncto UU No.17 Tahun 1985 , laut dapat dipartisi dalam persil-persil untuk pengusahaan dan pemanfaatannya, contoh: untuk ruang usaha ekonomis seperti budidaya ikan, rumput laut, kerang, penambangan dasar laut; sebagai ruang laut konservasi laut lindung dan taman nasional; sebagai ruang laut wisata dan rekreasi; serta sebagai ruang laut publik seperti alur pelayaran, pelabuhan dan sebagainya (Rais, 2003).

Penelitian ini bertujuan untuk mengkaji implementasi kadaster laut dan visualisasi 3 dimensi ruang laut berdasarkan kedalaman pada zona perikanan budidaya di Pulau Maratua. Studi kasus penelitian ini adalah di Pulau Maratua. Pulau Maratua merupakan satu dari 111 pulau kecil terluar yang ditetapkan pada Keputusan Presiden RI No 6 Tahun 2017 yang saat ini telah memiliki rencana zonasi pemanfaatan ruang laut. Menurut Pasal 1 ayat 1 Undang-Undang No 1 Tahun 2014 menjelaskan bahwa pengelolaan wilayah pesisir dan pulau-pulau terkecil adalah suatu pengoordinasian perencanaan, pemanfaatan, pengawasan, dan pengendalian sumber daya pesisir dan pulau-pulau kecil yang dilakukan oleh
Pemerintah dan Pemerintah Daerah, antarsektor, antara ekosistem darat dan laut, serta antara ilmu pengetahuan dan manajemen untuk meningkatkan kesejahteraan rakyat.

Rencana Zonasi adalah rencana yang menentukan arah penggunaan sumber daya tiap-tiap satuan perencanaan disertai dengan penetapan struktur dan pola ruang pada kawasan perencanaan yang memuat kegiatan yang boleh dilakukan dan tidak boleh dilakukan serta kegiatan yang hanya dapat dilakukan setelah memperoleh izin (Pemerintah Republik Indonesia. 2014). Wilayah perencanaan RZWP-3-K sesuai pasal 18 terdiri dari wilayah darat mencakup wilayah administrasi kecamatan dan ke arah laut sejauh 12 mil laut yang diukur dari garis pantai atau yang telah ditetapkan oleh undangundang. Untuk wilayah perairan laut sampai 2 mil laut diutamakan untuk Kawasan Konservasi, ruang penghidupan dan akses kepada nelayan kecil, nelayan tradisional, pembudidaya ikan kecil, dan petambak garam kecil, wisata bahari berkelanjutan, dan infrastruktur publik.

\section{METODE}

Lokasi penelitian (Gambar 1) yang digunakan pada penelitian ini yaitu Pulau Maratua. Secara administrasi, pulau ini terletak di Kecamatan Maratua, Kabupaten Berau, Provinsi Kalimantan Timur dan secara geografis terletak pada koordinat $2^{\circ} 11^{\prime} 27^{\prime \prime}$ LU- $118^{\circ} 36^{\prime} 26^{\prime \prime}$ BT. RZWP-3K Pulau Maratua Tahun 2016, data eksisting penggunaan ruang laut Pulau Maratua Tahun 2016, kontur kedalaman perairan Pulau Maratua Tahun 2016 menjadi bahan untuk kajian implementasi kadaster laut dan visualisasi 3D pemanfaatan ruang laut. Overlay data RZWP-3-K dan data eksisting selanjutnya di analisis untuk mengidentifikasi dan mengetahui kesesuaian pemanfaatan ruang laut. Sedangkan tumpang tindih data tersebut dengan data kontur untuk mengetahui nilai kedalaman laut dari setiap rencana zonasi. selanjutnya dilakukan penentuan sampel pemanfaatan ruang laut yang akan digunakan untuk pembuatan model 3 dimensi. 


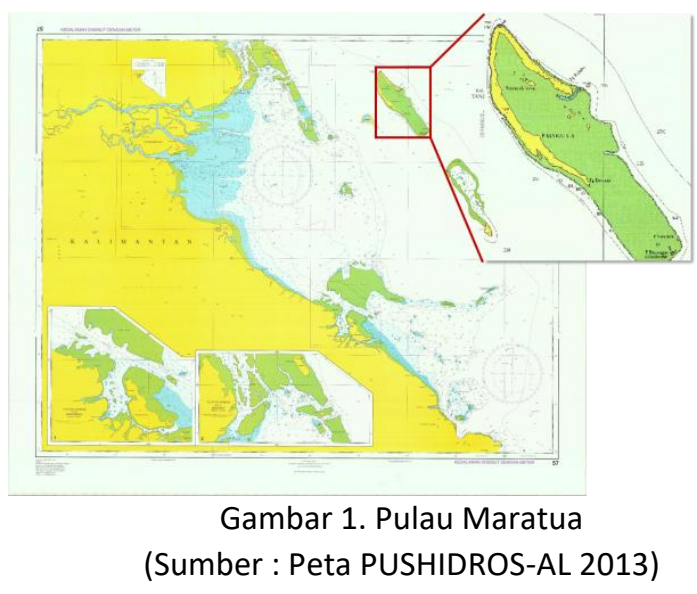

Penentuan sampel dilakukan pada KJA eksisting yang berada pada lebih dari 1 zona pemanfaatan ruang laut sehingga dapat dilakukan visualisasi pemanfaatan ruang laut secara vertikal. Pembuatan Model 3D Pemanfaatan Ruang Laut pada data sampel yang telah dilakukan dengan membagi pola pemanfaatan ruang laut berdasarkan kedalaman pada KJA yang berada pada lebih dari 1 rencana zonasi .

\section{HASIL DAN PEMBAHASAN}

Pembuatan peta dasar kadaster laut dihasilkan dari pengumpulan beberapa data pendukung utama peta dasar seperti data batas administrasi, data toponimi, dara eksisting dan juga data kontur yang memberikan informasi tentang kedalaman perairan lokasi studi. Berikut adalah hasil dari peta dasar kadaster laut yang dibuat dengan skala $1: 50.000$ (lihat Gambar 2). Diketahui bahwa Pulau Maratua terdapat empat desa, yang terdiri dari Desa Teluk Alulu yang disimbolkan oleh warna kuning, Desa Teluk Harapan yang disimbolkan oleh warna biru, Desa Payung-Payung yang disimbolkan oleh warna merah tua, dan Desa Bohe Silian yang disimbolkan oleh warna merah muda. Sedangkan Keramba Jaring Apung (KJA) yang terdapat di perairan Pulau Maratua adalah sebanyak 6 unit yang disimbolkan oleh poligon berwarna hijau seperti pada Gambar 2 .

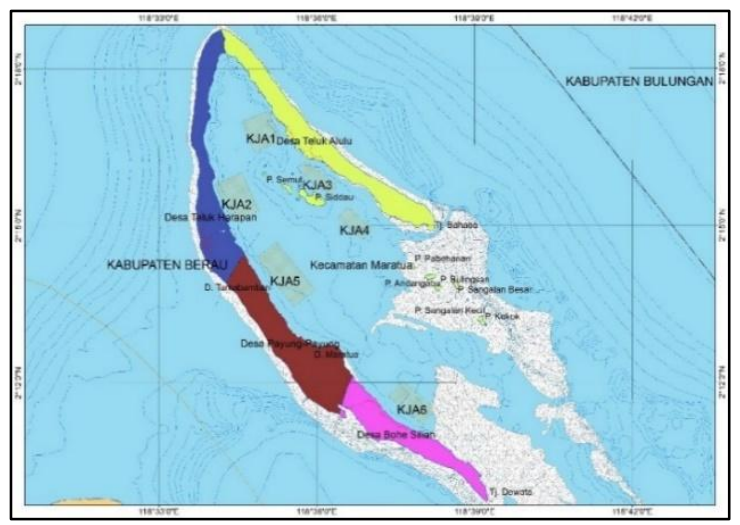

Gambar 2.Peta Dasar Kadaster Laut

Hasil identifikasi diketahui bahwa terdapat tiga unit Keramba Jaring Apung (KJA) yang tidak sesuai. Ketidaksesuaian ini diakibatkan dari lokasi penempatan Keramba Jaring Apung (KJA) tidak tepat pada subzona perikanan budidaya yang telah direncanakan dalam RZWP-3-K adapun sample yang dipilih adalah Keramba Jaring Apung (KJA) nomor lima karena memiliki tiga penggunaan ruang laut dalam satu unit. Secara detail dapat dilihat pada Gambar 3.

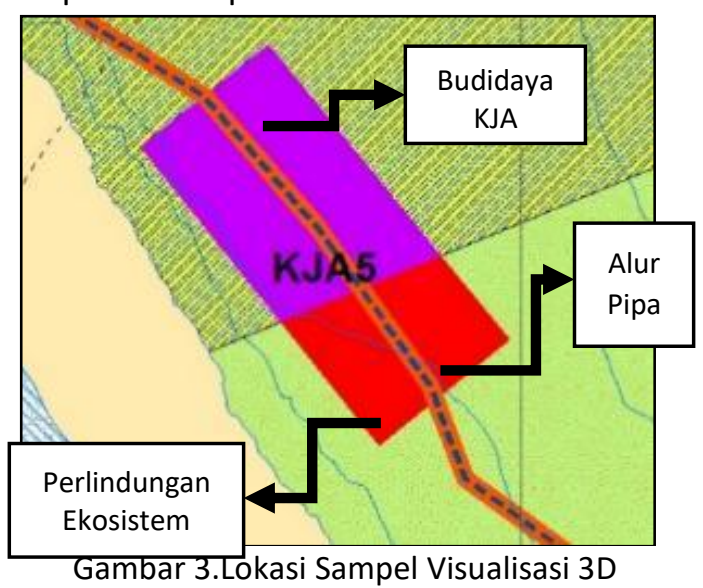

Dari Gambar 3 di atas diketahui bahwa Keramba Jaring Apung (KJA) nomor lima berada pada subzona perikanan budidaya, beberapa bagian berada pada subzona perlindungan ekosistem dan juga dilalui oleh alur pipa.

Pemodelan 3D menggunakan perangkat lunak SketchUp 2015. Visualisasi secara 3D ditinjau dari kedalaman dan kegiatan yang dilakukan pada masing-masing layer pemanfaatan ruang laut. 
Adapun hasil visualisasi tersebut dapat diuraikan melalui Gambar 4.

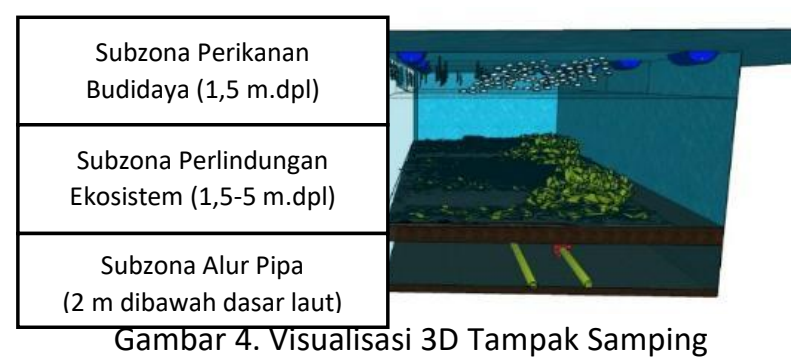

Adapun gambaran visualisai 3D yang dilakukan pada Keramba Jaring Apung (KJA) nomor 5 juga dapat dilihat tampak atas seperti dijelaskan pada Gambar 5.

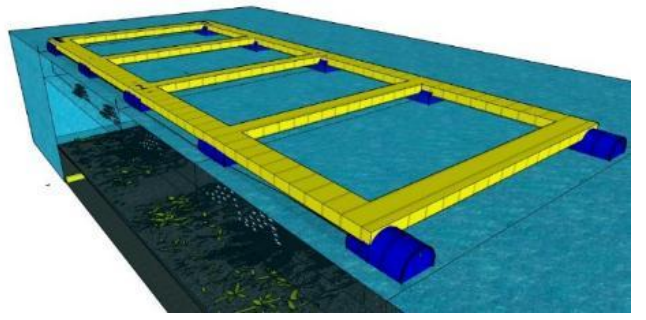

Gambar 5. Visualisasi 3D Tampak Atas

Dari beberapa Gambar diatas dapat diketahui bahwa dalam penggunaan ruang laut Keramba Jaring Apung (KJA) yang diberikan izin lokasi pada permukaan laut ternyata jika dianalisis secara vertikal menggunakan data kedalaman memiliki beberapa kegunaan. Adapun detail penggunaan ruang laut tersebut dapat dijelaskan pada Tabel 1 dibawah ini

Tabel 1. Detail Penggunaan Ruang Laut 3 Dimensi

\begin{tabular}{|c|c|c|c|}
\hline No & Jenis Kegiatan & Kedalaman & Dasar Penentuan \\
\hline 1. & $\begin{array}{l}\text { Perikanan } \\
\text { Budidaya }\end{array}$ & $\begin{array}{l}\text { 1,5 m dibawah } \\
\text { permukaan } \\
\text { laut } \\
1,5-5 \mathrm{~m}\end{array}$ & $\begin{array}{l}\text { RZWP-3-K dan Peta } \\
\text { Batimetri }\end{array}$ \\
\hline 2. & $\begin{array}{l}\text { Perlindungan } \\
\text { Ekosistem }\end{array}$ & $\begin{array}{l}\text { Dibawah } \\
\text { permukaan } \\
\text { laut }\end{array}$ & $\begin{array}{l}\text { RZWP-3-K dan Peta } \\
\text { Batimetri }\end{array}$ \\
\hline 3. & $\begin{array}{l}\text { Pipa Bawah } \\
\text { Laut }\end{array}$ & $\begin{array}{l}2 \text { m dibawah } \\
\text { permukaan } \\
\text { laut }\end{array}$ & 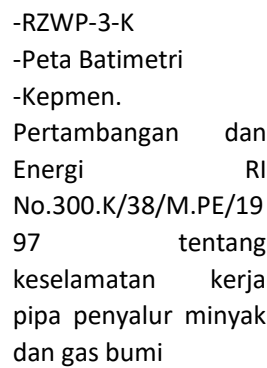 \\
\hline
\end{tabular}

\section{KESIMPULAN}

Kesimpulan yang dapat diambil dari penelitian ini adalah sebagai berikut:

1. Terdapat ketidaksesuaian pemanfaatan ruang laut yaitu Keramba Jaring Apung (KJA) no. 5 yang tumpang tindih dengan subzona perlindungan ekosistem.

2. Visualisasi 3D dari permukaan hingga dasar laut yang dilakukan pada titik uji KJA diperoleh informasi bahwa dalam area dimanfaatkan lebih dari 1 kegiatan, yaitu perikanan budidaya pada permukaan, perlindungan ekosistem pada kolom air, dan alur pipa laut pada dasar laut.

\section{DAFTAR PUSTAKA}

BPS-RI. 2015. Luas Laut Indonesia. <URL:https://www.bps.go.id/linkTabelStatis/vi ew/id/1366>.Dikunjungi pada 10 Nopember 2017, jam 11.04 .

Rais, Jacub. 2003. "Marine Cadastre" di Indonesia, Suatu Konsep Penataan Ruang Wilayah Laut. Salindia Presentasi CRMP-BPN RI. Jakarta.

Pemerintah Republik Indonesia. 2014. UndangUndang Republik Indonesia Nomor 1 Tahun 2014 Tentang Perubahan Atas Undang-Undang Nomor 27 Tahun 2007 Tentang Pengelolaan Wilayah Pesisir dan Pulau-Pulau Kecil. Jakarta. 